\title{
Characterization of Spent Bleaching Earth as an Adsorbent Material for Dye Removal
}

\author{
Andriyan Yulikasari', Ervin Nurhayati ${ }^{*}$, Widya Utama ${ }^{2 *}$, Idaa Warmadewanthi' \\ 1 Departement of Environmental Engineering, Institut Teknologi Sepuluh Nopember, Jl. Teknik Kimia, Keputih, \\ Kec. Sukolilo, Kota SBY, Jawa Timur 60111, Indonesia \\ 2 Departement of Geophysical Engineering, Institut Teknologi Sepuluh Nopember, Jl. Teknik Kimia, Keputih, \\ Kec. Sukolilo, Kota SBY, Jawa Timur 60111, Indonesia \\ * Corresponding author's e-mail: ervin@enviro.its.ac.id; widya@geofisika.its.ac.id
}

\begin{abstract}
Initial research has been carried out to determine the potential of SBE as an adsorbent material through chemical and surface area characterization. Several analyses were performed, including oil content, BET, SEM-EDS, XRD, FTIR, and adsorption capacity. The oil content of the SBE samples were $0.05-0.09 \%$, well below the standard (3\%) of hazardous material classification according to the Indonesian government regulation. The chemical composition of SBE, measured by EDS, was dominated by $\mathrm{Si}$ and $\mathrm{Al}$ elements. XRD analysis revealed two 2-theta diffraction peaks indicated the presence of crystalline $\mathrm{SiO}_{2}$ and $\mathrm{Al}_{2} \mathrm{O}_{3}$ phases. Additionally, the results of the FTIR test also showed the dominance of Si-O and Al-O-H functional groups. The SBE morphology, as observed in SEM image, exhibited irregular shape and porous surface covered by impurities. These results supported by the BET data which showed SBE surface area of $10.86 \mathrm{~m}^{2} \mathrm{~g}^{-1}$ and a mesopore volume of $2.49 \mathrm{~cm}^{3}$ (STP) $\mathrm{g}^{-1}$. Batch adsorption study conducted using low and high range concentration of methylene blue produced a maximum adsorption capacity of $7.993 \mathrm{mg} / \mathrm{g}$ and $40.485 \mathrm{mg} / \mathrm{g}$, respectively. The adsorption isotherm analysis showed that the adsorption mechanism was in accordance with the Langmuir isotherm model. Considering its chemical characteristic, SBE has met the criteria for adsorbent material. Nevertheless, the small surface area requires SBE to be activated prior to use.
\end{abstract}

Keywords: adsorbent, adsorption capacity, surface area, SBE.

\section{INTRODUCTION}

Bleaching earth (BE) is a natural material akin of active clay, commonly used to adsorb pigments of CPO. To produce 1 million tons of CPO, $0.5-1 \%$ $\mathrm{BE}$ which is equivalent to 34 thousand tons of Spent Bleaching Earth (SBE) were generated as solid waste. The increase of vegetable oil production within two years was accompanied by the increase of SBE solid waste from 184,162 tons in 2017 and reached 778,894 tons in 2019 [pslb3.menlhk.go.id]. According to the new Indonesian government regulation, the SBE wastes with less than 3\% residual oil content are not classified as hazardous waste [PP No. 22 of 2021]. It opens the opportunities to manage the SBE waste at a lower cost, including reuse it for other purposes, which was not possible according to the old regulation [PP No. 101 of 2014].
The approach for SBE waste management should implement the 3R (Reduce, Reuse, Recycle) concept to minimize the rate of waste generation. Various efforts have been widely made by several parties to reuse SBE, such as for a filler in NPK fertilizer [Purba et al., 2019], substitute for cement [Sharom, 2016], substitute for briquette raw materials [Sabarina et al., 2010], and as landfill material [Utama, 2020]. Although many studies have been carried out to reuse SBE, the accumulation of wasted SBE at the final disposal site is still high in Indonesia, reaching more than 50\% of the total production [pslb3.menlhk.go.id]. The wide variety of SBE reuse is expected to reduce this accumulation. Therefore, additional research is required to contribute to solving this problem.

Bleaching earth is one of the types of montmorillonite clay, which belongs to the smectite 
group with various chemical compositions with its volumes that can expand and shrink. Additionally, there are high negative charges on the mineral double layer structure. This type of smectite clay is able to accept and absorb metal ions and organic cations [Loh et al., 2015]. SBE is composed of aluminosilicate materials of $\mathrm{SiO}_{2}$ and $\mathrm{Al}_{2} \mathrm{O}_{3}$ with the percentage of $60-80 \%$, contains oil residues of about $20-40 \%$ and additional component of phosphoric acid $\left(\mathrm{H}_{3} \mathrm{PO}_{4}\right)$. The aluminosilicate content enables SBE to trap particles on the surface so that it can adsorb dyes [Damayanti, 2019]. In this study, an analysis of the surface area, composition, and adsorption capacity of the SBE material was carried out to find out the characteristics of SBE as an adsorbent material in a more detailed manner, which would be useful to determine the next effective and efficient utilization step.

\section{MATERIALS AND METHODS}

\section{Materials}

This study used the SBE waste from one of the oil companies in Gresik Regency, East Java Province, Indonesia. The SBE from this company has undergone the process of oil extraction and high temperature combustion. Therefore, the material characterized in this study is classified as DSBE (De-oiled Spent Bleaching Earth).

\section{Characterization}

SBE was tested for residual oil content prior to being used. Surface analyses were performed to determine the physical and chemical characteristics, such as morphological and elemental content analysis by SEM-EDS (JEOL-JSM-6390), crystalline phase by XRD (Philips X-Pert Pro-MPD), and surface functional groups by FTIR (Bio-Rad FTS-3500). The surface area and porosity of the material were analyzed by BET (BEL JAPAN).

\section{Adsorption capacity test}

The adsorption capacity of SBE was tested by performing the batch adsorption test using methylene blue solution. The standard methylene blue solution was made with the variation concentration of $5,10,15,20,25$, and $30 \mathrm{mg} / \mathrm{L}$, with its absorbance measurement at the maximum wavelength of $665 \mathrm{~nm}$. A total of 1-gram SBE was placed into 50
$\mathrm{mL}$ of methylene blue solution with of low concentrate variations of $30,60,90,120,150,180 \mathrm{mg} / \mathrm{L}$, and high concentrations of 200,300,400, 500, and $600 \mathrm{mg} / \mathrm{L}$. An Erlenmeyer glass contained the mixture of methylene blue solution and SBE was then stirred with a magnetic stirrer at the speed of 400 rpm for 120 minutes. The adsorbent was separated from the solution by filtration using Whatman filter paper no. 42. The obtained filtrate was then diluted 5 times for the low concentration and 20 times for the high concentration. The concentration of methylene blue before and after adsorption was determined by UV-vis spectrophotometry.

\section{Adsorption isotherm model: Langmuir and Freundlich}

The adsorption mechanism of SBE is analyzed using Langmuir and Freundlich isotherm models. The Langmuir isotherm model was associated with adsorption process through the single layer formation process (monolayer). This model is based on the assumption of homogeneous distribution of adsorption site, constant adsorption energy, neglectable interactions between adsorbate molecules [El-Sayed, 2011]. The Langmuir linear isotherm model can be expressed by Eq.

$$
\frac{C e}{q e}=\frac{1}{K l q m}+\frac{1}{q m} C e
$$

The Freundlich isotherm represents multilayer adsorption on the heterogeneous surface with the considerable interaction between the adsorbed molecule with the distribution of its non-uniform absorption energy between the surfaces [Sadaf \& Bhatti, 2014]. The equation model can be defined by Eq. (2).

$$
\log q e=\log K f+\frac{1}{\mathrm{n}} \log C e
$$

where: Ce represents the equilibrium concentration of adsorbate $(\mathrm{mg} / \mathrm{L}), q e$ is the amount of adsorbate which was absorbed by the adsorbent $(\mathrm{mg} / \mathrm{g}), \mathrm{Kl}$ is the ratio of adsorption and desorption rate $(\mathrm{L} / \mathrm{mg}), q m$ is the maximum adsorption capacity $(\mathrm{mg} / \mathrm{g}) . K f$ $[\mathrm{mg} / \mathrm{g}(\mathrm{L} / \mathrm{mg}) \mathrm{n}]$ is the Freundlich constant which is related to the adsorption capacity (referring to the quantity of adsorbate in the adsorbent) and $\mathrm{n}$ is the Freundlich constant which indicates the intensity of adsorption. The value of $\mathrm{n}$ gives an indication of how well the adsorption process is. 


\section{RESULTS AND DISCUSSION}

\section{Oil content}

The value of residual oil content in SBE can reach above 30\% [Wafti et al., 2011] and up to $40 \%$. The residual oil content that is too high can inhibit the performance of adsorbent. The residual oil content contained in SBE can be determined through the extraction process. This research used SBE that has been undergoing de-oiling process through petroleum benzene in Soxhlet extraction method. This treatment aims to increase the SBE surface area by removing the impurities attached to the SBE surface. The test results showed that the oil content of SBE samples were within the range of $0.05-0.09 \%$. Having oil content in this range, this SBE is excluded from hazardous material classification according to Indonesian Government which set the standard below 3\%. Due to the tendency of the residual oil to oxidize and the autocatalytic property of SBE, the direct landfill of SBE at local locations as a traditional disposal route leads to spontaneous self-ignition of SBE and other environmental problems. In this context, several viable recycling strategies to alleviate the SBE disposal problems have been reported, such as the production of biofuels, bio-lubricants and biodiesel. The regeneration of SBE as an inexpensive water / waste water adsorbent through chemical, physical and thermal processes is viewed as an interesting topic [Merikhy et al., 2020].

\section{Surface area and porosity}

The BET theory is developed from Langmuir's theory because it can be applied to any layer (multilayer) in which, physically, gas molecules can be adsorbed onto an infinite layer of solids. The BET test aims to determine the surface area of the material, the pore distribution of the material, and the pore volume of the SBE. The BET test in this study resulted in the surface area of the SBE material which can be seen in Table 1.

Table 1. BET test result of SBE material

\begin{tabular}{|l|c|c|}
\hline \multicolumn{1}{|c|}{ Parameter } & Value & Unit \\
\hline $\mathrm{V}_{\mathrm{m}}($ Volume mesopore $)$ & 2.4969 & {$\left[\mathrm{~cm}^{3}(\mathrm{STP}) \mathrm{g}^{-1}\right]$} \\
\hline $\mathrm{a}_{\mathrm{s}, \mathrm{BET}}($ Surface area $)$ & 10.868 & {$\left[\mathrm{~m}^{2} \mathrm{~g}^{-1}\right]$} \\
\hline $\begin{array}{l}\text { Total pore volume } \\
\left(\mathrm{p} / \mathrm{p}_{0}=0.315\right)\end{array}$ & 0.0056131 & {$\left[\mathrm{~cm}^{3} \mathrm{~g}^{-1}\right]$} \\
\hline Mean pore diameter & 2.066 & {$[\mathrm{~nm}]$} \\
\hline
\end{tabular}

On the basis of Table 1, the average pore diameter of SBE is $2.066 \mathrm{~nm}$. The pore diameter of SBE is related to the ability of the pores to absorb the adsorbate from a particular fluid. This diameter affects the density and porosity of the SBE material. Larger pore diameter value is related to the smaller density value. The pore diameter surely affects the adsorption capacity of SBE, because more fluid can flow in the pores. Thus, the value of the pore volume is positively correlated to the adsorption ability of SBE.

On the basis of the results of BET test, the volume of SBE mesoporous value is $2.49 \mathrm{~cm}^{3}$ $(\mathrm{STP}) \mathrm{g}^{-1}$. The greater value of the surface area of the SBE, the more pores will be in the unit area of SBE. From the test results, the surface area value $\left(\mathrm{a}_{\mathrm{s}, \mathrm{BET}}\right)$ is $10.86 \mathrm{~m}^{2} \mathrm{~g}^{-1}$. Similar results have been reported by [Majid \& Mat, 2017], wherein the obtained value of surface area was $19.4 \mathrm{~cm}^{2} \mathrm{~g}^{-1}$. This value is relatively smaller compared to other adsorbent materials which able to have a surface area above $100 \mathrm{~m}^{2} \mathrm{~g}^{-1}$. In another study, Activated Spent Bleaching Earth (ASBE) with the acidheating combination method had a surface area of $100.38 \mathrm{~m}^{2} \mathrm{~g}^{-1}$ [Sabour \& Shahi, 2018]. Similar result was also reported by Meziti \& Boukerroui [2012] who produced an ASBE surface area of $153 \mathrm{~m}^{2} \mathrm{~g}^{-1}$. Thus, SBE must be activated to increase the surface area to its maximum value to match or exceed the other adsorbents.

\section{Surface morphology and elemental content}

The SBE characteristics based on SEM image are used to see the surface morphology structure, grain size, structural defects, and pollution composition. The results of SEM image obtained using $1000 \mathrm{x}$ and 2000x magnification can be seen in Figure 1. Morphology of SBE appears to have an irregular surface, relatively spherical shape and has pores. The narrow pore space may indicate the presence of impurity compounds which filled some of the pore spaces in SBE. The SBE morphology is shaped like flakes and large spheres with irregular shapes that show the morphology of montmorillonite [Mana et al., 2007; Sabour et al., 2017].

The EDS test aims to determine the composition of the elements or the constituent elements of SBE material. The EDS analysis is based on the comparison of measurement results of X-ray intensity ratio, generated by the elements in the material sample with similar element from the 

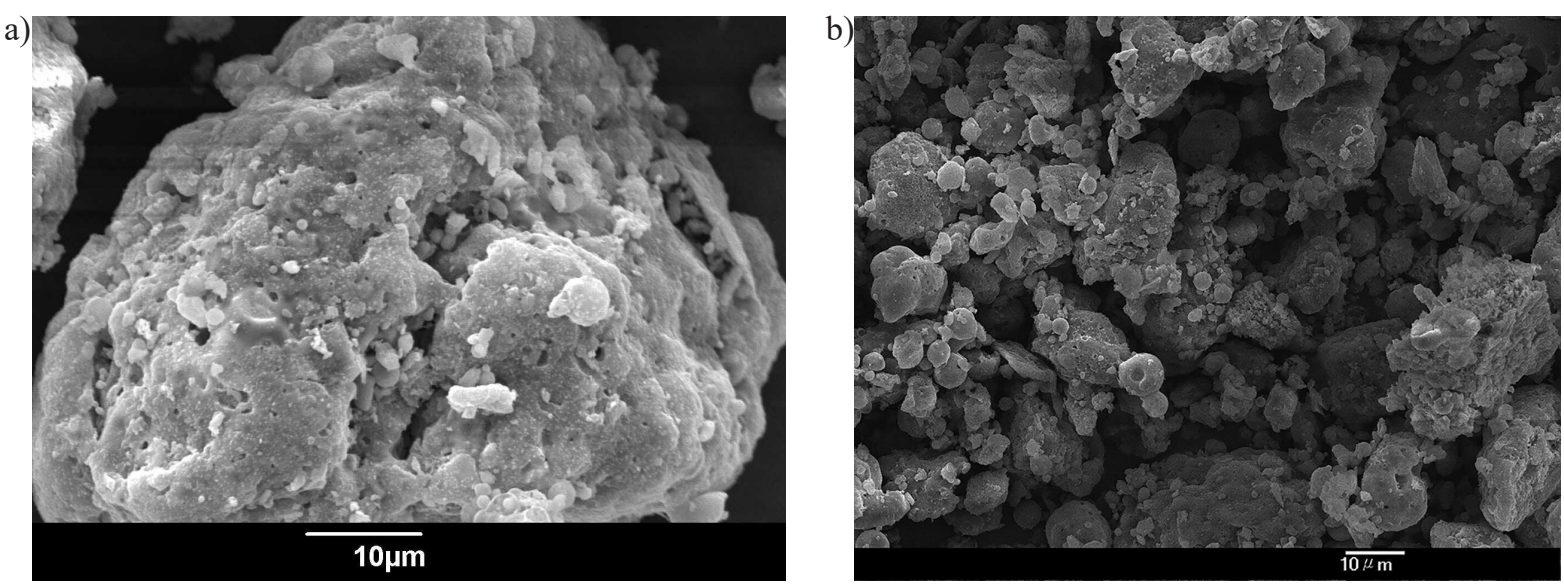

Figure 1. SEM image of SBE material under (a) 2000x, (b) 1000x magnification

standard sample. The X-rays characteristics generated from each element are proportional to the concentration of the element, the probability of Xray production or ionization of the element, and the path length of the electrons. This characteristic is compared with the standard value to obtain the components of the SBE material. The results of the EDS spectrum are shown in Figures $2 a$ and $2 b$.
Figure 2a shows that SBE component contains of the following substance, sequentially from the most to the least based on weight \%: $\mathrm{O}$ (30.46\%), Si (30.13\%), Fe (11.94\%), Al (9.03\%), $\mathrm{Zr}(6.80 \%), \mathrm{Ca}(4.40 \%), \mathrm{Mg}(2.39 \%), \operatorname{Pt}(2.23 \%)$, $\mathrm{K}(1.48 \%)$ and $\mathrm{Ti}(1.15 \%)$. Meanwhile, Figure $2 \mathrm{~b}$ contains the following substance sequentially from the most to the least based on weight \%: $\mathrm{O}$
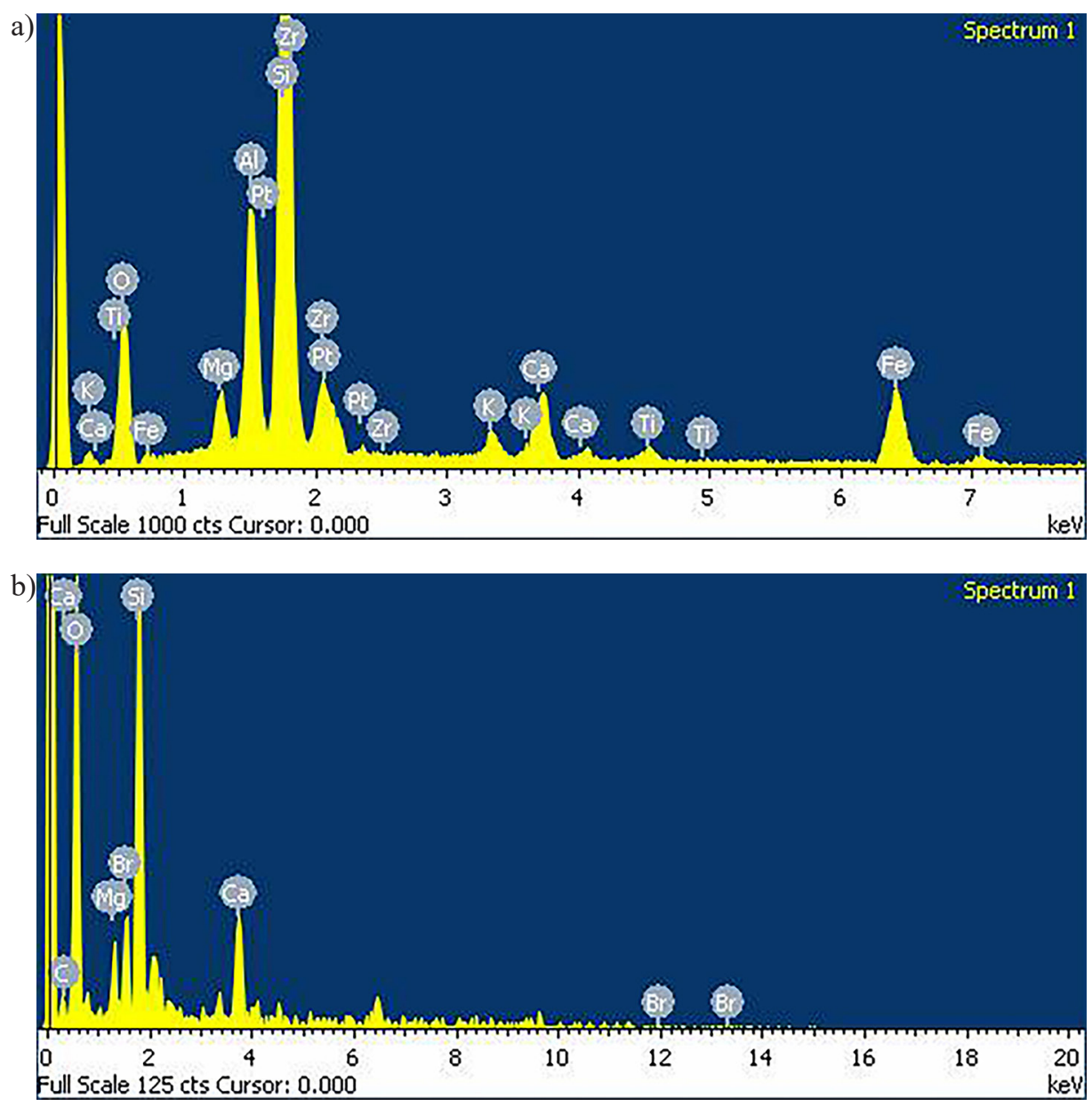

Figure 2. EDS Test Results for SBE Materials 
(51.75\%), Si (21.20\%), Ca (9.53\%), C (7.08\%), $\mathrm{Br}(7.80 \%)$, and $\mathrm{Mg}(2.65 \%)$. Similar things is also found by Suryani et al., [2015] with O, Si, and $\mathrm{Al}$ as the dominant elements of SBE. The adsorption ability of SBE is caused by Al element on the surface of the trap particles so that it can adsorb the adsorbate and depends on the comparison of Si and Al elements [Damayanti, 2019].

The result of the EDS test shows that the SBE material is classified as Ca-montmorillonite and contains several impurities, such as $\mathrm{Fe}, \mathrm{Ca}, \mathrm{Mg}$, $\mathrm{Br}, \mathrm{Zr}$, Ti, Pt, and $\mathrm{K}$, which fill the surface of SBE [Merikhy et al., 2019]. The appearance of C element in SBE indicates that there is an organic compund and residual oil which left behind during bleaching process, but the amount is only $7.08 \%$. Extraction process of residual oil has been done toward SBE material based on the residual oil test, showing a very small amount of $0.05-0.09 \%$. However, the impure elements has fulfill around $30 \%$ of SBE surface, which caused the results of SBE surface area to small with the value of $10.86 \mathrm{~m}^{2} \mathrm{~g}^{-1}$.

\section{Cristallinity}

The XRD analysis aims to determine the nature of amorphous and crystalline phases formed in SBE. The basic principle of XRD testing is to diffract light that passes through the crystal slit and comes from a radius with a wavelength equivalent to the distance between atoms of about 1 Angstrom. The results of the XRD test shows that: (1) the position of diffraction peak which can provide an overview of the lattice parameters, the distance between the fields, the crystal structure and the orientation of the unit cell; (2) the relative intensity of the diffraction peaks gives an idea of the atomic position in the unit cell; (3) the shape of the diffraction peaks gives an idea of the crystallite size and lattice imperfections. The results of XRD testing of the SBE materials can be seen in Figure 3.

On the basis of Figure 3, it can be seen that the peak diffraction shows the characteristic of mineral montmorillonite, quartz, and a little bit of minor crystal [Farahiyah et al., 2020; Hindryawati et al., 2019; Sabour et al., 2017]. The XRD test analysis shows that the peak diffraction of two 2-theta between $20^{\circ}$ to $50^{\circ}$ shows the appearance of montmorillonite $\left(\mathrm{Al}_{2} \mathrm{O}_{3} \cdot 4 \mathrm{SiO}_{2} \cdot \mathrm{H}_{2} \mathrm{O}\right)$ and quartz $\left(\mathrm{SiO}_{2}\right)$ minerals. The peak diffraction of two 2-theta shows the $\mathrm{SiO}_{2}$ from the SBE sample which appeared on $20.8299^{\circ}, 21.7561^{\circ}, 25.4454^{\circ}$, $26.6214^{\circ}, 36.5271^{\circ}, 39.4329^{\circ}, 62.7940^{\circ}$, and $67.8940^{\circ}$. On the basis of the mineralogy analysis, the $\mathrm{SBE}$ contains $\mathrm{SiO}_{2}$ in both crystal phase and amorphous phase. The peak diffraction of two 2-theta indicates aluminum oxide $\left(\mathrm{Al}_{2} \mathrm{O}_{3}\right)$ which appeared on $35.5537^{\circ}, 43.2784^{\circ}, 50,0869^{\circ}$, and $53.8783^{\circ}$. There are other minor crystals contained in SBE which is calcite, shown by the peak diffraction two 2-theta of $29.3915^{\circ}$.

\section{Surface functional group}

The FTIR spectroscopy method is an infrared spectroscopic method equipped with Fourier transform to analyze the spectrum results. Figure 4 shows the infrared spectrum from the FTIR spectroscope test of the SBE sample. The FTIR analysis of the SBE sample shows the structure of montmorillonite and the characteristic of residual oil in the

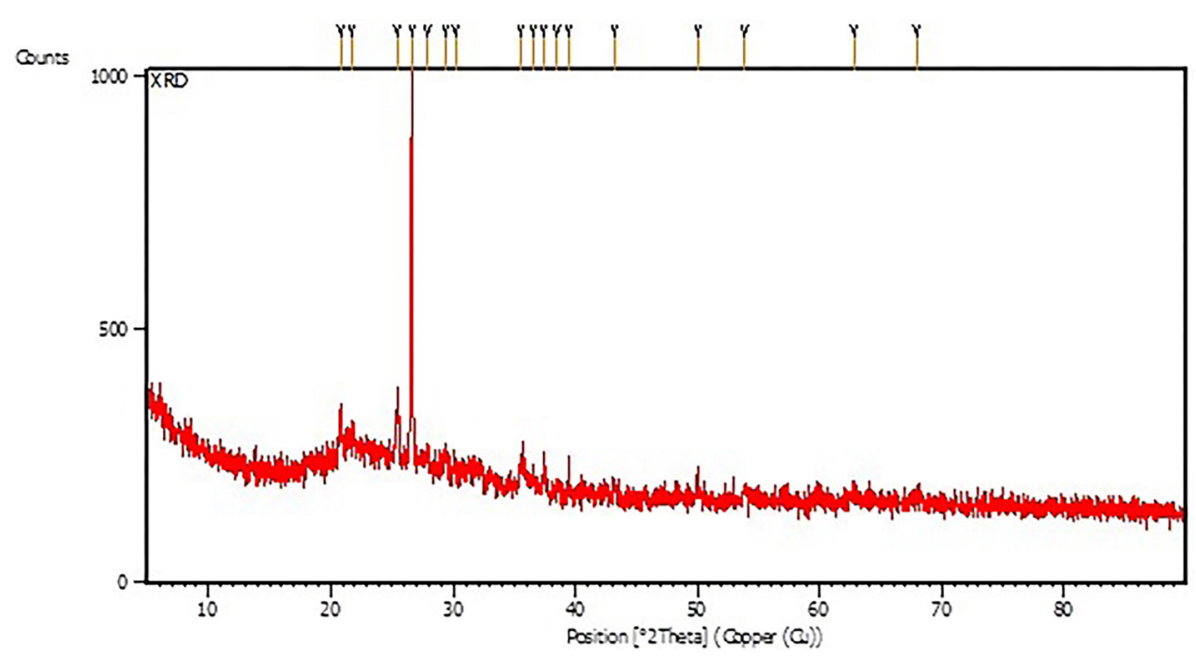

Figure 3. XRD test result of SBE material 


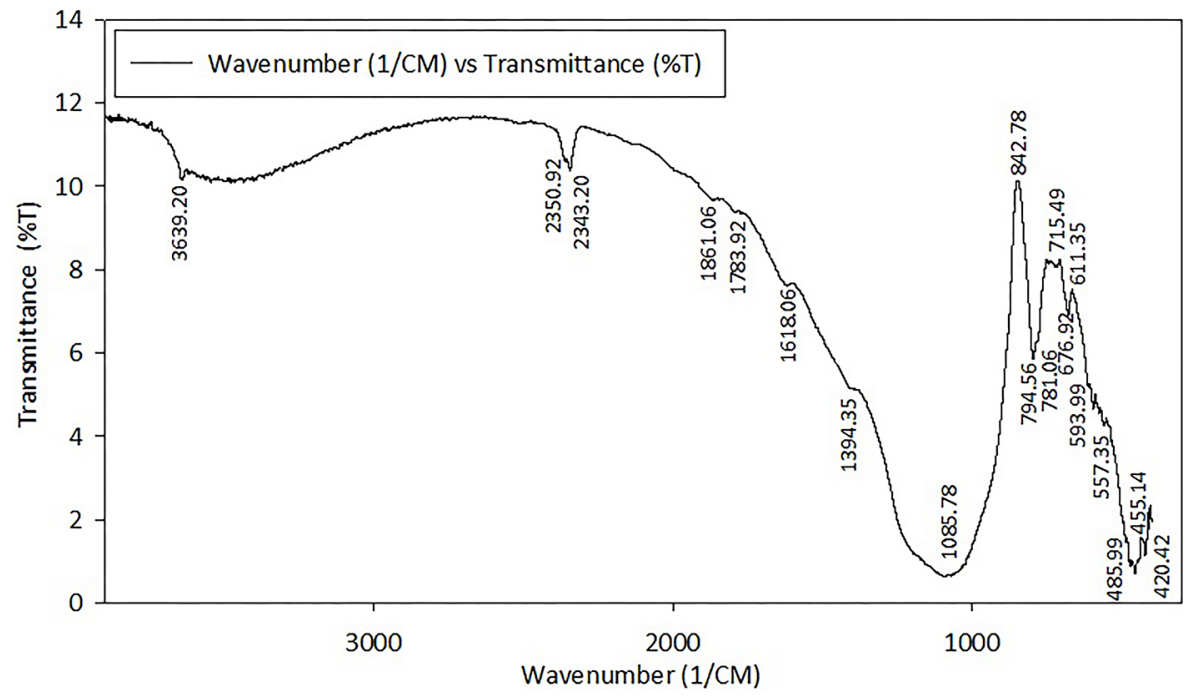

Figure 4. FTIR test result of SBE material

resulting spectrum range [Hindryawati et al., 2019; Merikhy et al., 2019; Sabour et al., 2017]. The spectrum adsorption near $3639 \mathrm{~cm}^{-1}$ shows the appearance of montmorillonite structure, which shows Al$\mathrm{O}-\mathrm{H}$ group strain. The group of Si-O can be seen in the spectrum adsorption of $1085 \mathrm{~cm}^{-1}$ (strain), spectrum of 751-794 $\mathrm{cm}^{-1}$ shows $\mathrm{Si}-\mathrm{O}$ vibration with the quartz impurities, spectrum of 611-676 $\mathrm{cm}^{-1}$ shows $\mathrm{Si}-\mathrm{O}$ vibration in kaolinite, spectrum of $557-593 \mathrm{~cm}^{-1}$ shows the changes of Si-O-Al structure, and spectrum of $420-485 \mathrm{~cm}^{-1}$ shows the vibration from $\mathrm{Si}-\mathrm{O}$ or $\mathrm{Si}-\mathrm{O}-\mathrm{Si}$ group. Meanwhile, the characteristic of residual oil appears at the spectrum range of $1394-2350 \mathrm{~cm}^{-1}$, there is a spectrum of $1394.067 \mathrm{~cm}^{-1}\left(\mathrm{CH}_{2}\right.$ vibration) which appears in this range value, spectrum of $1618 \mathrm{~cm}^{-1}(\mathrm{O}-\mathrm{H}$ vibration), spectrum of 1783-1861 $\mathrm{cm}^{-1}$ (ester carbonyl strain), and spectrum of $2343-2350 \mathrm{~cm}^{-1}$ (it can be $\mathrm{C}-\mathrm{H}$ strain or an alkene $\mathrm{C}=\mathrm{C}$ strain structure). The whole spectrum range can be seen in Figure 4.

\section{Adsorption capacity and isotherms}

Figure 5a shows the methylene blue used for the experiment arranged in the order from low concentration (left) to high concentration (right), while Figure $5 \mathrm{~b}$ shows the same solution after adsorption process. From these figures, it can be clearly observed that the lower initial concentration of methylene blue resulted in a clearer final solution. The most striking change was visually obvious at the concentration of $30 \mathrm{mg} / \mathrm{L}$ (Figure $5 \mathrm{a}$ and $5 \mathrm{~b}$ on the far left), where the blue color completely disappeared after the adsorption process. Under this condition, the adsorption capacity reached $1.48 \mathrm{mg} / \mathrm{g}$.
Model of isotherm adsorption is able to give the information about adsorption maximum capacity to evaluate adsorbent performance [Wang $\&$ Guo, 2020]. Figure 6 shows the Langmuir and Freundlich isotherm models as the calculation result of methylene blue adsorption. The mathematic equation model in Figure 6 shows that adsorption at low concentration was better fitted to the Langmuir model at Figure 6a Eq. (3) compared to the Freundlich model at Figure 6c Eq. (5). The same thing happened to the mathematical equation

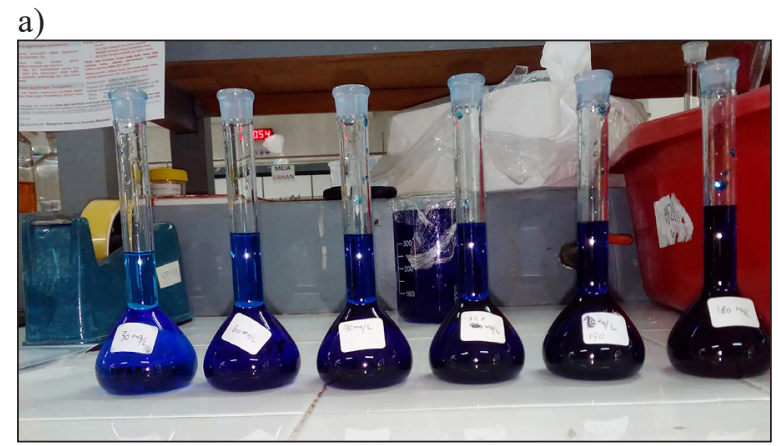

b)

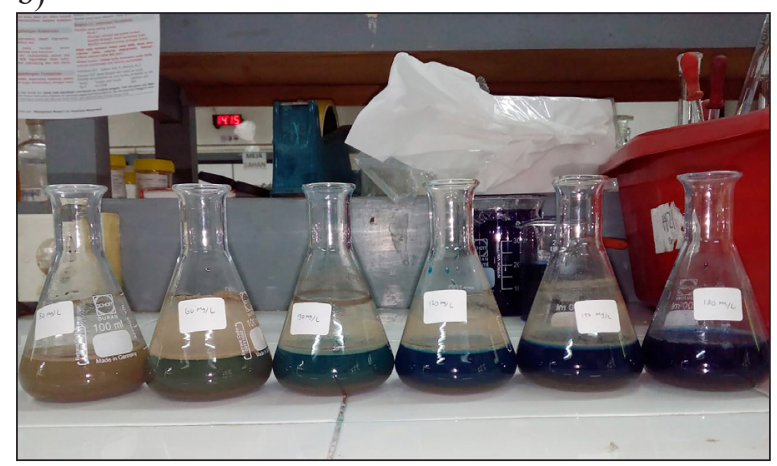

Figure 5. Adsorption test on methylene blue; a) before adsorption, b) after adsorption 
model at high concentration was better fitted to the Langmuir model at Figure 6b Eq. (4) compared to the Freundlich model at Figure 6d Eq. (6).

$$
\begin{gathered}
\frac{1}{q e}=0.2187\left(\frac{1}{C e}\right)+0.1251 \\
\frac{1}{q e}=2.7635\left(\frac{1}{C e}\right)+0.0247 \\
\log q e=0.4443 \log q e+0.4163 \\
\log q e=0.621 \log q e+0.0311
\end{gathered}
$$

The coefficient correlation value of the Langmuir isotherm model (Eq. (3) and Eq. (4)) in the adsorption mechanism at low and high concentration of methylene blue are 0.9971 and 0.9938 . Meanwhile, the coefficient correlation values of the Freundlich isotherm model (from Eq. (5) and Eq. (6)) are 0.9648 and 0.9863 . The appropriate value of a good correlation $(\geq 0.9)$ shows that the result test of the Langmuir and Freundlich isotherm models have given an excellent result. Therefore, the Langmuir and Freundlich isotherm
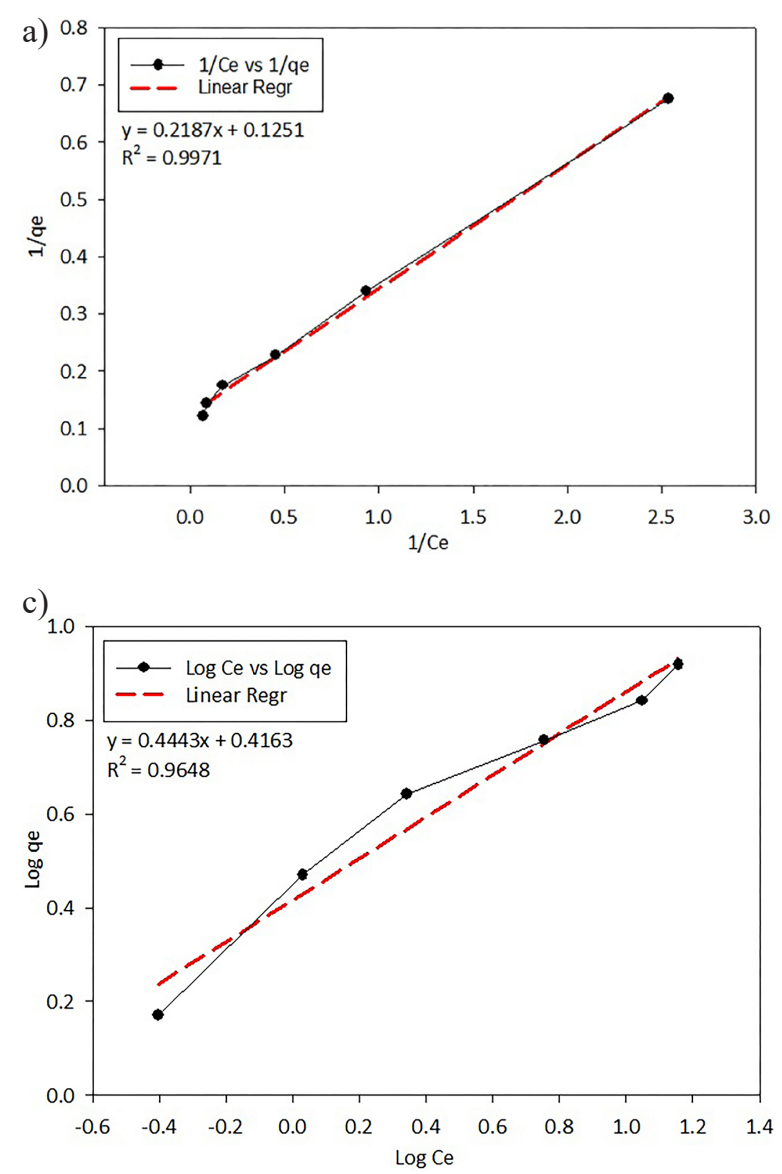

models can be used in the adsorption mechanism of methylene blue with SBE adsorbent.

Although the difference is not significant, the mechanism of methylene blue adsorption by SBE is more in line with the Langmuir isotherm model compared to the Freundlich isotherm model, both in low and high concentration. The Freundlich isotherm model shows the presence of heterogeneous adsorption of more than one surface layer (multilayer) on the surface of the SBE pore space. However, the difference in binding energy for each layer in the adsorption process follows the Langmuir isotherm model. Therefore, the determination of the maximum adsorption power of SBE in the methylene blue absorption process was carried out using the Langmuir isotherm adsorption equation, which is the adsorption of a single layer (monolayer) of methylene blue on each surface of SBE with units of $\mathrm{mg}$ of adsorbed methylene blue/gram SBE. The Langmuir isotherm model shows the distribution of homogeneous adsorption site and constant adsorption energy. Thus, based on the calculation, the maximum capacity of SBE to adsorb methylene blue in low and high concentration is $7.993 \mathrm{mg} / \mathrm{g}$ and $40.485 \mathrm{mg} / \mathrm{g}$, respectively.
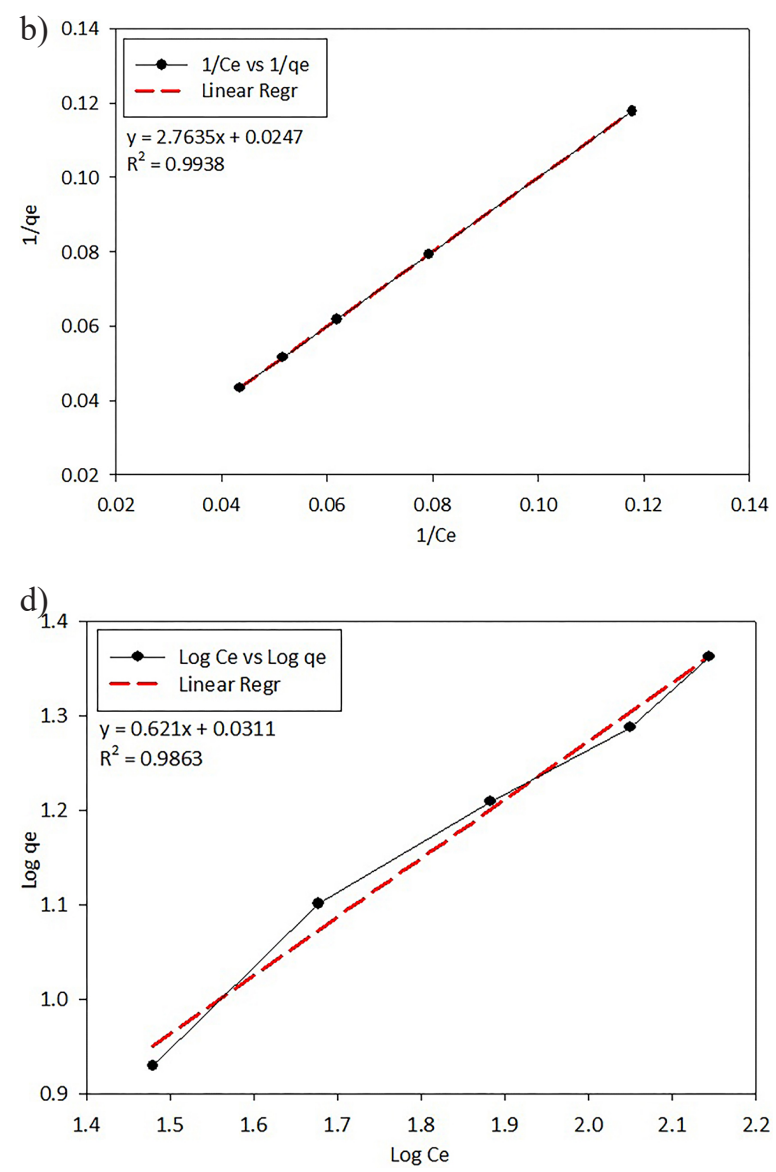

Figure 6. Methylene blue adsorption by SBE modeled by the Langmuir and Freundlich isotherm 


\section{CONCLUSIONS}

On the basis of the characteristic test of SBE regarding both of surface morphology of the pore space and the composition of the chemical components, the results obtained indicate that the SBE has the potential to become an adsorbent material. The $\mathrm{Si}$ and $\mathrm{Al}$ elements dominated in the EDS analysis, and there is a dominance of $\mathrm{SiO}_{2}$ and $\mathrm{Al}_{2} \mathrm{O}_{3}$ crystalline phase in a few peak diffractions as well as the domination of aluminosilicate functional group. However, SBE is classified as the material with a small surface area, which is $10.868 \mathrm{~m}^{2} / \mathrm{g}$ based on the surface characteristic. The batch study using methylene blue shows the maximum adsorption capacity of $7.993 \mathrm{mg} / \mathrm{g}$ and $40.485 \mathrm{mg} / \mathrm{g}$ at low and high concentration with the adsorption mechanism following the Langmuir isotherm model.

This adsorption capacity can still be increased again through the SBE activation process with the chemical, physical, or combination chemical/ physical method. In this method, the adsorption test will be investigated by considering the $\mathrm{pH}$ effect, reaction time effect, stirring speed effect, adsorbent mass effect and the effect of adsorbate concentration. This study aimed to improve the operational performance of SBE as an adsorbent. In the future, it is expected that SBE can be used as a raw material for adsorbent material as part of the efforts to utilize the SBE waste and simultaneously to overcome the pollution of the water environment by hazardous material adsorbate.

\section{Acknowledgements}

The author would like to thank Directorate of Research and Community Service - Institut Teknologi Sepuluh Nopember (ITS), Indonesia for the research funding. We also like to thank National Taiwan University of Science and Technology (NTUST) for helping test samples in his laboratory.

\section{REFERENCES}

1. Damayanti C. 2019. Pengaruh Jenis dan Konsentrasi Asam Terhadap Proses Reaktivasi Spent Bleaching Earth (SBE) Hasil Samping Produksi Biosolar. Bachelor. Thesis Fakultas Pertanian Universitas Lampung. (in Indonesian)

2. El-Sayed G.O. 2011. Removal of Methylene Blue and Crystal Violet From Aqueous Solutions by Palm
Kernel Fiber. Desalination, 272(1-3), 225-232. https://doi.org/10.1016/j.desal.2011.01.025

3. Farahiyah R., Rahman A., Asrah H., Rizalman A.N., Abdul K., Rajak M.A.A. 2020. Study of Eco-Processed Pozzolan Characterization as Partial Replacement of Cement. Journal of Environmental Treatment Techniques, 8(3), 967-970.

4. Hindryawati N., Panggabean A.S., Julia D., Subagyono N., Putri R. A., Kusmiaty P., \& Maniam G. 2019. Modification of Spent Bleaching Earth with $\mathrm{WO}_{3}$ and The Application for Photocatalytic Degradation of Waste Dyestuff under Solar Light. Jurnal Bahan Alam Terbarukan, 8(2), 84-89.

5. Loh S.O.H.K., Cheong K.A.H.Y., Choo Y.M.A. Y. 2015. Formulation and Optimisation of Spent Bleaching Earth-Based Bio Organic Fertiliser. Journal of Oil Palm Research, 27(1), 57-66.

6. Majid R.A., Mat C.R.C. 2017. Regenerated Spent Bleaching Earth for The Decolourisation and Bod Reduction of Palm Oil Mill Effluent. Journal of Oil Palm Research, 29(4), 579-587. https://doi. org/10.21894/jopr.2017.0006

7. Mana M., Ouali M., Menorval L.C.D. 2007. Removal of Basic Dyes From Aqueous Solutions With a Treated Spent Bleaching Earth. Journal of Colloid and Interface Science, 307, 9-16. https://doi. org/10.1016/j.jcis.2006.11.019

8. Merikhy A., et al. 2020. Carbonized Spent Bleaching Earth as a Low-Cost Adsorbent: A Facile Revalorization Strategy Via Respone Surface Methodology. Chemical Engineering and Processing-Process Intensification, 158(2020), 108167. https://doi. org/10.1016/j.cep.2020.108167

9. Merikhy A., Heydari A., Eskandari H., Nematollahzadeh A. 2019. Revalorization of Spent Bleaching Earth a Waste from Vegetable Oil Refinery Plant by an Efficient Solvent Extraction System. Waste and Biomass Valorization, 10(10), 3045-3055. https://doi.org/10.1007/s12649-018-0311-0

10. Meziti C., Boukerroui A. 2012. Removal of a basic textile dye from aqueous solution by adsorption on regenerated clay. Procedia Engineering, 33(2009), 303-312. https://doi.org/10.1016/j. proeng.2012.01.1208

11. Purba R.S., Irwan S.N.R., Putra E.T.S. 2019. The Effect of Spent Bleaching Earth Filler-Based NPK Fertilization on Proline, Growth and Yield of Maize. Caraka Tani. Journal of Sustainable Agriculture, 35(1), 44. https://doi.org/10.20961/carakatani. v35i1.34166

12. Sabarina F., Manik F. 2010. Pemanfaatan Spent Bleaching Earth Dari Proses Pemucatan CPO Sebagai Bahan Baku Briket. Bachelor. Thesis. Fakultas Teknologi Pertanian Institut Pertanian Bogor. (in Indonesian) 
13. Sabour M.R., Shahi M., Dezvareh G.A. 2017. Reactive Dye Extraction Utilizing Regenerated Bleaching Earth. Global Journal of Environmental Science and Management, 3(3), 299-310. https://doi. org/10.22034/gjesm.2017.03.03.007

14. Sabour, Reza M., Shahi M. 2018. Spent Bleaching Earth Recovery of Used Motor-Oil Refinery. Civil Engineering Journal, 4(3), 572. https://doi. org/10.28991/cej-0309116

15. Sadaf S., Bhatti H.N. 2014. Batch And Fixed Bed Column Studies for The Removal of Indosol Yellow BG Dye by Peanut Husk. Journal of the Taiwan Institute of Chemical Engineers, 45(2), 541-553. https://doi.org/10.1016/j.jtice.2013.05.004

16. Sharom N.B.I.N. 2016. Performance of Eco Process Pozzolan Foamed Concrete as Cement Replacement.
Faculty of Civil Engineering \& Earth Resources. Universiti Malaysia Pahang.

17. Suryani A., Pari G., Aswad A. 2015. Proses Reaktivitas Tanah pemucat Bekas sebagai Adsorben untuk Pemurnian Minyak Sawit Kasar dan Biodiesel. Jurnal Teknologi Industri Pertanian, 25(1), 52-67. (in Indonesian)

18. Utama W. 2020. Characteristic of Spent Bleaching Earth Substitution in Limestone as Landfill Material. Journal of Marine-Earth Sciene Technology, 1, 37-42.

19. Wafti N.S.A. et al. 2011. Regeneration and Characterization of Spent Bleaching Clay. Journal of Oil Palm Research, 23(April), 999-1004.

20. Wang J., Xuan G. 2020. Adsorption Isotherm Model: Classification, Physical Meaning, Application and Solving Method. Chemosphere, 258, 127-279. 